\title{
THE ROLE OF CLASSROOM INTERACTION IN STUDENTS' SPEAKING SKILL (A Case Study Research In Senior High School)
}

\author{
${ }^{1}$ Gina Larasaty, ${ }^{2}$ Yutinih \\ English Education Department \\ Wiralodra University - Indramayu ( West Java) \\ 1ina_larasaty@Unwir.ac.id, ${ }^{2}$ yutinih407@gmail.com
}

\begin{abstract}
.
This study is aimed at finding out how the role of classroom interaction in students' speaking skill by showing the role of student-student interaction and student-teacher interaction inside classroom. While, the students often found some problems in learning speaking; one of the problem that they faced was lack of interaction in classroom. According to Warda (2015:2) "lack of interaction in EFL classes, could be the first lead to student's oral poor productions." Allwright (1984:156) defined interaction as the fundamental fact of classroom pedagogythe fact that everything that happens in the classroom happens through a process of live-person-to-person interaction. Classroom interaction then is the one of facilitator to start conversation, as Nunan (1991:50) argued in two-way tasks (conversational interaction), all participants have a piece of informational known only to them which must be contributed to the small group discussion for the task to be completed successfully. The writer used qualitative research design and took one of the kinds of qualitative research method, which is a case study. The data obtained from the triangulation instruments. The first instrument was observation, this instrument helped the writer to find out the real situation in classroom especially the students' interaction in speaking class, the second instrument was questionnaire, this instrument was to classify and determine how frequently interaction in classroom, the third instrument was the data transcript from interview. The results show that $92 \%$ of the students are aware about the important of classroom interaction in their speaking skill and $56 \%$ of them need their teacher to be guider as well as motivator with the number $24 \%$ to encourage them to interact and speak in the classroom. And students really need the teacher to provide more opportunities to interact with her, which according to their responses $68 \%$ of them prefer student-teacher interaction the most. In fact, students seem to know one of good students' qualities is speaking and interacting in classroom, since refraining classroom interaction and showing no interest will naturally affect their speaking ability.
\end{abstract}

Keywords: interaction, classroom interaction, and speaking skill 


\begin{abstract}
Abstrak
Penelitian ini bertujuan untuk mengetahui bagaimana peran interaksi kelas dalam keterampilan berbicara siswa dengan menunjukkan peran interaksi siswa-siswa dan interaksi siswa-guru di dalam kelas. Sementara, siswa sering menemukan beberapa masalah dalam belajar berbicara; Salah satu masalah yang dihadapi siswa adalah kurangnya interaksi di kelas Menurut Warda (2015: 2) "kurangnya interaksi dalam kelas EFL, bisa menjadi penyebab utama produksi oral siswa kurang bagus." Allwright (1984: 156) mendefinisikan interaksi sebagai fakta mendasar dari pedagogik kelas - fakta bahwa semua yang terjadi di kelas terjadi melalui proses interaksi langsung-orang-ke-orang. Interaksi kelas adalah salah satu fasilitator untuk memulai percakapan, seperti Nunan (1991: 50) berpendapat bahwa interaksi kelas, semua peserta memiliki potongan informasi yang hanya diketahui oleh mereka yang harus dikontribusikan untuk diskusi kelompok kecil untuk tugas yang akan diselesaikan dengan sukses. Penulis menggunakan desain penelitian kualitatif dan mengambil salah satu jenis metode penelitian kualitatif, yaitu studi kasus. Data yang diperoleh dari instrumen triangulasi. Instrumen pertama adalah observasi, alat ini membantu penulis untuk mengetahui situasi nyata di kelas terutama interaksi siswa di kelas berbicara, instrumen kedua adalah kuesioner, instrumen ini adalah untuk mengklasifikasikan dan menentukan seberapa sering interaksi di kelas, instrumen ketiga adalah data transkrip dari wawancara. Hasil penelitian menunjukkan bahwa 92\% dari siswa menyadari tentang pentingnya interaksi kelas dalam 'keterampilan berbicara mereka dan $56 \%$ dari mereka membutuhkan guru mereka menjadi penuntun sekaligus motivator dengan jumlah 24\% untuk mendorong mereka untuk berinteraksi dan berbicara di kelas. Dan siswa benar-benar membutuhkan guru untuk memberikan lebih banyak kesempatan untuk berinteraksi dengannya, yang menurut tanggapan mereka, 68\% dari mereka lebih memilih interaksi siswa-guru. Bahkan, siswa tampaknya tahu salah satu kualitas siswa yang baik adalah berbicara dan berinteraksi di kelas, karena menahan interaksi kelas dan tidak menunjukkan minat akan secara alami mempengaruhi kemampuan berbicara mereka.
\end{abstract}

Kata Kunci : Kata kunci: interaksi, interaksi kelas, dan keterampilan berbicara

\section{INTRODUCTION}

Speaking is one of the important skills in learning English. Luoma (2004:1) stated "speaking skills are an important part of the curriculum in language teaching, and this makes them an important object of assessment as well." and sometimes students find it difficult to communicate or interact using English. According to Nunan (2001:165) "In the era of communicative language teaching, interaction is, in fact, the heart of 
communication; it is what communication is all about."

In classroom language learning, the effective environment is the one in which every students have the opportunity to speak and interact. Through the interaction, students' oral performance will be developed because it encourages students to express themselves in a meaningful way. As Chadia (2011:4) "Interaction develops learners' performance in speaking a foreign language, since they are given the chance to develop their speaking and listening skills in oral expression classes." Saaied (2015:22) added “....learners are always looking for opportunities to talk and show their abilities in this language Classroom interaction is then, the only setting where they can share ideas and express their needs with the guidance of the teacher of course." Thus, there is relationship between interaction and the development of speaking skill because students are able to exchange thoughts, feelings, or ideas through interaction.
Meanwhile, many students found some problems in learning speaking. As Al-Saadi, Tonawanik and Al Harthy (2013:78) stated "Despite of the fact that speaking is considered one of the most crucial language skills, many students have major problem in mastering even the basics of this important language skill." The first problem that students often found in speaking is anxiety; foreign language classroom can create anxiety easily. "Some learners feel that a little nervousness before an oral performance or speaking in the class." (Benlagha 2014:56). Hadfield (2008:106) added "learner who is shy to speak in their own language may find it even more difficult in a new language."The second problem, if teacher provides students speaking activities, the students do not respond or are not willing to participate actively in classroom. As Hadfield (2008:105) in such responsive class "alternatively may get one or two learners who are willing to speak, while the rest remain silent." 
The third problem, students are often confused on how to start to talk in classroom as a member of group when the others prefer to keep quit. As Kouicem (2009:17) stated "In such classrooms, learners get little or no practice of how to initiate or to end the talk." "Learners are often inhibited about trying to say things in a foreign language in the classroom." (Ur, 1991:121)The fourth problem, some students are also less-motivation during the speaking activities. Quenan $(2014: 21) \quad$ stated "it has been problem or a difficulty for most EFL teachers because their students have low motivation to speak English." Less-motivation in learning also causes students' hesitation to speak English in the classroom. The last problem, lack of interaction in the classroom, it is because students have some speaking difficulties. According to Warda (2015:2) "Lack of interaction in EFL classes, and lack of the teacher's encouragement and support for learners to interact in the learning environment, could be the first lead to student's oral poor productions."

Based on the explanation above, the writer makes this journal with the title "The Role of Classroom Interaction in Students' Speaking Skill" (A case study in class XI at SMAN 1 Tukdana). This study is expected in the presence of both students and teacher can take advantage and get better and be able to improve education quality in line with the continuous passing of an era of high mobility today. However, a teacher must know that their students have some level of intelligence that must be considered as well.

\section{Speaking Skill}

There are many definitions of speaking that have been proposed by some experts in language learning. Luoma (2004:1) stated “speaking skills are an important part of the curriculum in language teaching, and this makes them an important object of assessment as well." While (Thornbury, 2005) "Speaking is interactive and requires the ability to 
co-operate in the management of speaking turns. It also typically takes place in real time, with little time for detailed planning." for him speaking is a skill, and as such needs to be developed and practiced independently of the grammar curriculum. In addition,Nunan (1989:27) “....Speaking skills is between monologue and dialogue. The ability to give an uninterrupted oral presentation is quite distinct from interacting with one or more other speakers for transactional and interactional purposes." Thus, Thus, speaking is an oral communication that expresses the meaning of words between two or more persons which can be observed directly. In speaking, the speaker is not only known about the competence of speaking but also performance of speaking so that other people can catch the idea of the speaker. Because of that speaking can be the central element of communication that sends a message from someone to the other.

\section{Classroom Interaction}

"classroom interaction is that known as 'IRF'- 'Initiation-ResponseFeedback': the teacher initiates an exchange, usually in the form of a question, one of student answer, the teacher gives feedback (assessment, correction, comment), initiates the next question, and so on."Hence, Allwright (1984:156) argues that interaction as "the fundamental fact of classroom pedagogy- the fact that everything that happens in the classroom happens through a process of live-person-to-person interaction." From the very beginning of language study classroom should be interactive.

one of facilitator to start conversation, as Nunan (1991) argued in two-way tasks (conversational interaction), all participants have a piece of informational known only to them which must be contributed to the small group discussion for the task to be completed successfully. Radia (2017:92) defined that conversational interaction is concerned range from 
the role of teacher questions in scaffolding learning to the role of interpersonal interactions in the learning of particular forms for creating peer solidarity to learner appropriation of strategies for facilitating their own and other's language learning. It can be conclude that classroom interaction is in which students interact with their teacher and peers, and they are learning to do conversation.

\section{METHOD}

This research is aimed to investigate the interaction during the teaching-learning process in senior high school. This study used qualitative research design and took one of the kinds of qualitative research method, which is a case study. As Nunan (1992:77) “...the case study researcher typically observes the characteristics of an individual unit- a child, a clique, a class, a school, or a community." Nunan (1992:76) cited in Yin (1984:23) also added that "A case study is an empirical inquiry that investigates a contemporary phenomenon within its real-life context, when the boundaries between phenomenon and context are not clearly evident, and which multiple sources of evidence are used."By choosing case study, it is clear in conducting this research, it does not doing any treatment.

To gain information for an accomplishment of this study, the writer had applied observation, questionnaire and interview. Observation of this study was to find out the real situation in classroom especially in speaking class. Questionnaire was to classify and determine how frequently interaction in classroom. And interview was used to fulfill researcher's question and to know students' responses about classroom interaction. .

Instrument is important thing in collection the data. The data would be gained should be appropriate and proper due to the data must correspond with what the researcher expects to answer in the formulation of problem. Therefore, the researcher believes that the data 
would be gained through Observation, Questionnaire, and Interview are suitable with this research.

\section{Observation}

This observation aimed to explore what goes on inside the classroom, either between the teacher and the students or among the students themselves. It is also the way of the writer to research the speaking class by looking the English teacher teaches their students and also to observe how frequently the interaction in the classroom. The writer used observation sheet adopted from BatiteTaous (2012). Observation items have been designed based on the writer's need. The observation is presented in a form of checklist including a set of items under two sections. The first section is designed for observing the management of the learning environment. And the second section is devoted for the observation of the students' interaction inside the classroom.

\section{Questionnaire}

The second data comes from questionnaire. According to Nunan (1992:143) "the questionnaire is the relatively popular means of collecting data. It enables the researcher to collect data in fields setting, and the data themselves are more amenable to quantification than discursive data such as free-form field notes, participant observers' journals, and the transcripts of oral language."

In order to accomplish this research the writer chose the questionnaire as the main tool of this research. 23 questions prepared to get the responses of the students. And the questionnaire was adapted from Meriem Benlagha (2014) and Guerza Radia (2017) consists of 23 items and divided into three sections. It contains both openended and close-ended questions meant to probe students' opinions 
about the effect interaction in the classroom on activating their speaking ability. Section one is about students' background information (items 1, 2). Section two: Students' Attitude towards Classroom Interaction (items 316). And section three: Students' Attitude towards Speaking Skill (17-23). The purpose of this questionnaire was to explore student's attitudes concerning the act of interacting in the classroom as well as their opinion about speaking abilities as a result of classroom interaction.

\section{Interview}

This is the last step to gain the data. The results of this interview becomes the important part to complete the analysis because several question will strengthen two others data, observations and questionnaire. In this part, the students are asked about their interaction in the classroom, their difficulty in speaking and what type of classroom interaction that encourage them to speak more in classroom. The interview is being made to the teacher and students by doing some conversation. The writer asked some question to obtain data concerning of the classroom interaction. Based on how the writer gained the data, the data analysis of this study belongs to qualitative data analysis.

\section{FINDINGS AND DISCUSSIONS}

This study was done successfully in SMAN 1 Tukdana, where students were interacting differently according to their speaking ability. Students were interacting in classroom especially when discussing such topics, but when teacher asked them to mention some word about the topic that arise in the first session, no one students who willing to speak until the teacher point out their names to mention some word and speak loudly. This mean when doing classroom 
interaction teacher should aware of the importance of the students' classroom interaction as an effective strategy to develop the students speaking skill inside the classroom. As Chadia (2011:4) argued that "Interaction develops learners' performance in speaking a foreign language, since they are given the chance to develop their speaking and listening skills in oral expression classes."

Based on the questionnaire and interview the researcher deduces that most of students are aware of the importance and the value of classroom interaction. Students' previous answers illustrate that they want to learn speaking and speak English well, and that they consider the speaking skill the measure of knowing the language but the problem is that they encounter some difficulties in learning English. When they were asked about which interaction that they prefer most, $68 \%$ of students said they prefer ST Interaction rather than SS Interaction. In contrast, at interview, 18 of students stated they feel more enjoy when doing SS Interaction even though they find difficulties when they want to interact with their partner, it indicated that students want to increase the frequent of their interaction with teacher but they feel uncomfortable when doing this, so that the teacher should aware of her students' need to develop their knowledge and their oral skill. Moreover the amount of the students' talk should be dominant in the classroom, and students really need the opportunities to speak and interact that given by teacher to experience producing foreign language through engaging in classroom interactions. Students who always remain silent in the classroom feel at loss of words when they were in situations where they pushed into communicative activities in order to make them participate in the classroom. In this case the silent students didn't know what are going to do in the classroom without guidance from the teacher. So, they need their teacher to be guider as well as motivator to encourage them to interact and speak. Classroom 
interaction can successfully lead students to promote their speaking capacities. However, this can happen through frequent interaction in the classroom with their classmates and their teacher because refraining classroom interaction and showing no interest will naturally affect the student's speaking ability.

The analysis of present study revealed that classroom interaction should be frequently either between the teacher or among students themselves in order to improve students' speaking skill since majority of their level in English was average, the students were aware that classroom interaction plays an important role in their speaking ability in classroom. These results also have shown that classroom interaction did not depend only on the students' themselves, but also it depends on the teachers' use of some effective teaching.

At the end of discussion, the researcher would like to provide some suggestion concerning to the classroom interaction and speaking.
The students should do their best to acquire a high oral competence through the interaction inside the classroom. In addition, they have to be more conscious about the importance of practicing the oral skill in the classroom since classroom interaction was regarded as the most suitable setting, where the students feel comfortable when using English. English teacher also need to provide a real classroom atmosphere with the best learning environment so that students can speak and interact freely in the classroom, since focusing on practice speaking skill inside the classroom will help students to be a good communicator. English teacher needs to know how to create motivation among students to make them communicate frequently. Since the teacher is the one who controls the instruction, she has the right to ask her students work in groups so that they benefit from each other, especially by practicing oral skill regularly. 


\section{CONCLUSION}

According to the result of this research, the writer has accomplished some of facts. The role of classroom interaction created situations for students to promote their speaking skill, where students work in pairs or groups fostering the exchange of knowledge, participation, and sharing ideas. Hence, the results obtained there were a positive relationship between classroom interaction and speaking skill. The findings presented in this research prove that $92 \%$ of the students are aware about the important of classroom interaction in their' speaking skill and $56 \%$ of them need their teacher to be guider as well as motivator with the number $24 \%$ to encourage them to interact and speak in the classroom. Teacher need to teach their students with the use of cooperative learning technique where students interact in pairs or groups. And students really need the teacher to provide more opportunities to interact with her, which according to their responses $68 \%$ of them prefer student-teacher interaction the most.
Based on the problem that the researcher did at SMA N 1 Tukdana, all the data results of classroom observation, students' questionnaire, and interview have revealed that the role classroom interaction in their speaking skill was very important. The analysis of students' classroom observation revealed that classroom interaction should be frequently either between the teacher or among students themselves in order to improve students' speaking skill since majority of their level in English was average, and the analysis of the students' questionnaire indicates that the students were aware that classroom interaction plays an important role in their speaking ability in classroom. These results also have shown that classroom interaction did not depend only on the students' themselves, but also it depends on the teachers' use of some effective teaching.

After having consulted the role of classroom interaction in students' speaking skill, the researcher provides some suggestions for students that will 
help them to be more interactive inside the classroom in order to develop their speaking skill. First of all, students have to think about the purpose of speaking that will help them to deal better with the topic discussion. Also, the students should do their best to acquire a high oral competence through the interaction inside the classroom. In addition, the students have to be more conscious about the importance of practicing the oral skill in the classroom since classroom interaction was regarded as the most suitable setting, where the students feel comfortable when using English. Moreover, the students should speak and interact in classroom regularly as an attempt to get rid of their shyness and hesitation. Furthermore, the students need to be aware about the necessity of the speaking skill as an important factor in language learning process.

Based on the results obtained, developing the students speaking skill can be said to be a fundamental aspect in learning and teaching process. To be a good communicator, it is necessary to focus on practicing speaking skill inside the classroom. English teachers need to provide a real classroom atmosphere with the best learning environment so that students can speak and interact freely in the classroom. Also, the teacher need to give much importance to the speaking skill by focusing on the discussion tasks which should meet the students' needs, level and interests. Also, English teacher needs to know how to create motivation among students to make them communicate frequently. Since the teacher is the one who controls the instruction, she has the right to ask her students work in groups so that they benefit from each other, especially by practicing oral skill regularly. 


\section{REFERENCES}

Allwright, R. (1984). The Importance of Interaction in Classroom Language Learning. University of Lancaster

Al-Saadi, S., Tonawanik, P., \& AlHarthy, S. (2013). Perspective Speaking Difficulties Faced by Omani Students: Empirical Data on Self - Perception. International Peer Reviewed Journal, 4(3), 77-78.

Benlagha, M. (2014).Enhancing EFL Learner's Speaking Skill through Classroom Interaction. Mohamed Khider University of Biskra.

Chadia, C. (2011). Interaction in Teachers/Learners and Learners/Learners' Discourse. University of Ferhat AbbasSetif.

Hadfield, J \& Hadfield, C. (2008). Introduction to Teaching English. Oxford: Oxford University Press.

Kouicem, K. (2009). The Effect of Classroom Interaction on Developing the Learner's Speaking Skill. The case of third year LMD students of English at Constantine University. Unpublished MA Thesis Mentouri University Constantine.
Nunan, D. (1991). Language Teaching Methodology. Prentice Hall: Macquarie University.

Nunan, D. (1992). Research Method in Language Learning. New York: Cambridge University Press.

Quenan, T. M. P. (2014). Classroom Interaction and The Speaking Skill. University of Naniro.

Radia, G. (2017). The Role of Conversational Interaction in Learning English as a Foreign Language in a Computer Mediated Classroom. University of Batna-2

Saaied, M, S. (2015). Enhancing EFL Learners' Speaking Skill through Classroom Interaction. University of Muhammad khiederBiskra.

Warda, S. (2015).The Importance of Classroom Interaction in Improving EFL Student's Speaking Skill. Mohamed Khider University of Biskra. 